\title{
Selective inhibition of apoptosis by TPA-induced differentiation of U937 leukemic cells
}

\author{
Olivier Sordet ${ }^{1}$, Ali Bettaieb1, Jean-Marie Bruey ${ }^{1}$, \\ Béatrice Eymin ${ }^{1}$, Nathalie Droin ${ }^{1}$, Michael Ivarsson ${ }^{1}$, \\ Carmen Garrido ${ }^{1}$ and Eric Solary ${ }^{*, 1}$ \\ ${ }^{1}$ Department of Biology and Therapy of Cancer, INSERM U517, JE 515, Faculty \\ of Medicine \& Pharmacy, 7, boulevard Jeanne d'Arc, 21033 Dijon, France \\ * corresponding author: Eric Solary, M.D., INSERM U517 Faculty of Medicine \& \\ Pharmacy, 7 boulevard Jeanne d'Arc, 21033 Dijon Cedex, France. tel: (33) 380 \\ 3932 26; fax: (33) 3802950 44; e-mail: esolary@u-bourgogne.fr
}

Received 19.8.98; revised 12.11.98; accepted 27.1.99

Edited by K.M. Debatin

\begin{abstract}
U937 leukemic cells treated for $24 \mathrm{~h}$ with $16 \mathrm{nM} 12-0$ tetradecanoylphorbol 13-acetate (TPA), that induces their macrophagic terminal differentiation, become resistant to etoposide-induced apoptosis. Exposure of undifferentiated U937 cells to $50 \mu$ Metoposide for $6 \mathrm{~h}$, that triggers apoptosis in $80 \%$ cells, activates procaspase $-2 \mathrm{~L},-3$ and -8 , induces the mitochondrial release of cytochrome $\mathrm{c}$ and decreases $\mathrm{Mcl}-1$ expression without modifying $\mathrm{Bcl}-2, \mathrm{Bcl}-\mathrm{xL}$ and $\mathrm{Bax}$ protein levels. All these events are inhibited in TPA-differentiated U937 cells that are also resistant to vinblastine-induced and Fas-mediated cell death. Interestingly, these cells are not inherently resistant to apoptosis induction. Exposure of TPAdifferentiated U937 cells to $0.8 \mu \mathrm{g} / \mathrm{ml}$ cycloheximide for $24 \mathrm{~h}$, that triggers apoptosis in $50 \%$ cells, activates procaspase-2L, -3 and -8 , induces the mitochondrial release of cytochrome $c$ and decreases Bcl-xL expression without modifying Bcl-2, Mcl-1 and Bax protein levels. All these events are not observed in undifferentiated cells treated in similar conditions. These results indicate that the apoptotic pathway that involves the release of cytochrome $c$ from mitochondria and the cleavage of procaspases remains functional in TPA-differentiated cells.
\end{abstract}

Keywords: differentiation; apoptosis; TPA; etoposide; cycloheximide; caspase; cytochrome c

Abbreviations: Fas-L, Fas-ligand; PARP, poly(ADP-ribose)polymerase; RB, retinoblastoma; TPA, 12-O-tetradecanoylphorbol 13-acetate

\section{Introduction}

Human myeloid leukemia cell lines can be induced to differentiate along the macrophagic pathway by treatment with the phorbol ester 12-O-tetradecanoylphorbol 13-acetate (TPA). ${ }^{1}$ This process of differentiation is associated with activation of protein kinase $C{ }^{2}$ down-regulation of $c-m y c^{3}$ and cdc25 expression, ${ }^{4}$ induction of c-fos, c-jun and c-fms transcripts $^{5-7}$ and cell cycle exit. ${ }^{8}$ Although differentiated cells ultimately die by apoptosis, ${ }^{9}$ we have previously shown that HL-60 cells induced to differentiate by TPA became resistant to drug induced cell death. ${ }^{10} \mathrm{~A}$ resistance to druginduced apoptosis has been also observed in vitamin $D_{3}$ differentiated HL-60 cells. ${ }^{11}$ Thus, terminally differentiated leukemic cells can be used as a model for comparing drugsensitivity of undifferentiated proliferating and differentiated quiescent tumor cells.

Apoptosis is the mode of cell death usually triggered by chemotherapeutic drugs in leukemic cells. ${ }^{12-14}$ It results from the activation of a genetically encoded suicide program that leads to a series of characteristic events including morphological changes, DNA fragmentation, externalization of phosphatidylserine on the outer leaflet of the plasma membrane and proteolysis of cellular substrates. We have previously identified a proteolytic cascade that was responsible for most of these events in etoposide-treated U937 leukemic cells. ${ }^{15} \mathrm{~A}$ family of cysteine proteases, referred to as caspases, plays a central role in this proteolytic cascade. ${ }^{16}$ Generation of active caspases requires limited proteolysis of a proenzyme at internal aspartate residues to give a heterodimeric enzyme with both chains containing essential components of the catalytic machinery. ${ }^{17}$ Whereas a few caspases are primarily involved in procytokine activation, most of them are considered to promote pathways to apoptosis. Caspases activate downstream procaspases in a cascade that induces a limited proteolysis of a number of cellular proteins including poly(ADP-ribose)polymerase (PARP), ${ }^{18}$ the retinoblastoma protein $(\mathrm{RB})^{19}$ and the cyclin-dependent kinase inhibitor p27 $7^{\text {Kip1 }}$ (Eymin et al, submitted).

Activation of some caspases such as caspase- 3 is modulated by members of the Bcl-2 family of proteins that either promote or inhibit apoptosis. Antiapoptotic members such as Bcl-2 itself, Bcl-xL and $\mathrm{Mcl}-1$ prevent apoptosis in response to a variety of stimuli whereas proapoptotic proteins such as Bax accelerate the death process. ${ }^{20-22}$ Most of these proteins are localized to the outer membrane of mitochondria and nucleus as a result of a carboxyterminal membrane anchor. ${ }^{22}$ Many of the biochemical changes associated with apoptosis can result from alterations in mitochondrial function. ${ }^{23,24} \mathrm{~A}$ current picture of cell death regulation is that most apoptotic signals converge on a common final pathway in which Bcl-2-related proteins modulate the release of resident mitochondrial proteins such as cytochrome $\mathrm{c}$ and apoptosis-inducing factor. ${ }^{25-29}$ In the cytosol, cytochrome c combines with the protein Apaf-1 and caspase- 9 to activate procaspase-3 and the proteolytic cascade that leads to apoptosis. ${ }^{30}$

In the present study, we compared the sensitivity of U937 parental cells and their TPA-differentiated counterpart to drug-induced and Fas-mediated apoptosis. We show that apoptosis triggered by etoposide, vinblastine and soluble 


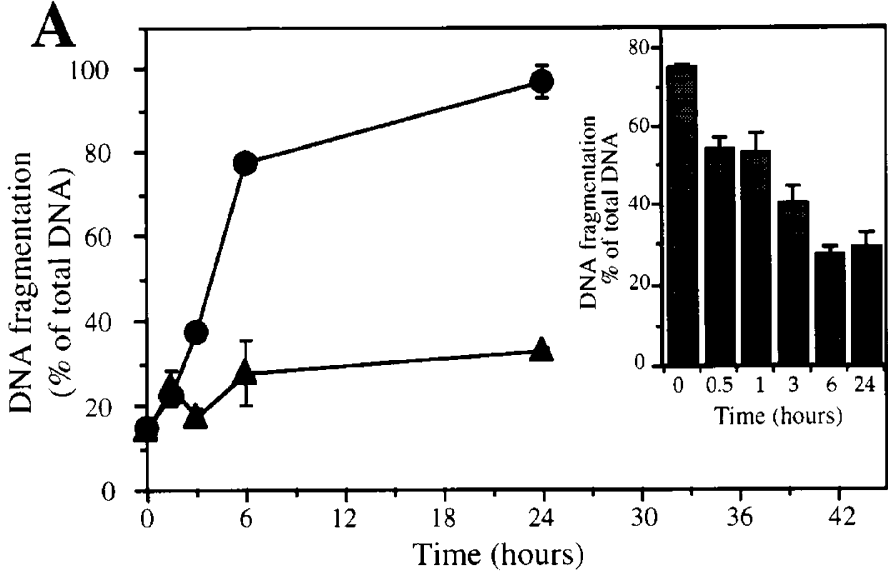

UD

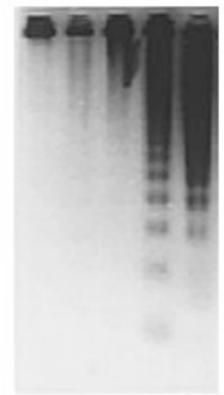

$\begin{array}{lllll}0 & 1.5 & 3 & 6 & 24\end{array}$
D

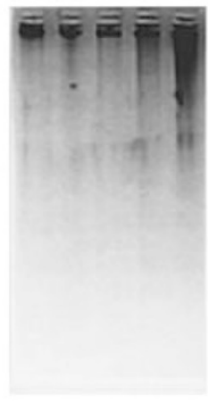

$\begin{array}{lllll}0 & 1.5 & 3 & 6 & 24\end{array}$

B
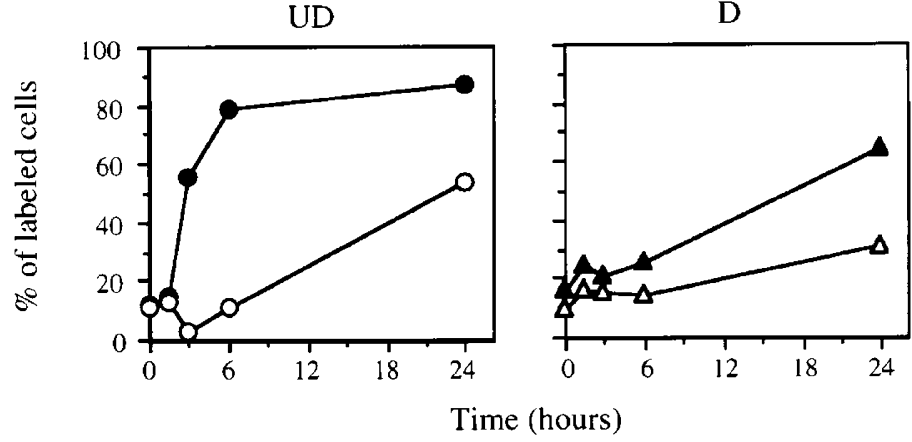

C

UD

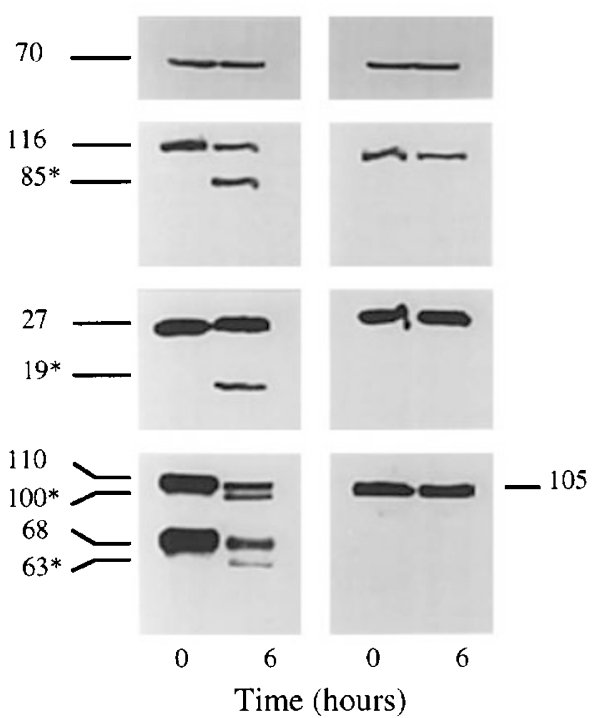

HSP70

PARP

RB

Figure 1 Inhibition of etoposide-induced apoptosis in TPA-differentiated U937 cells. Parental undifferentiated (UD, ) and TPA-differentiated (D, $\mathbf{\Delta}$ ) U937 cells were treated with $50 \mu \mathrm{M}$ etoposide for indicated times. (A) Apoptotic DNA fragmentation was quantified using filter elution assay [One of two independent experiments is shown (mean \pm S.D. of triplicate samples)] (left panel) and visualized by agarose gel electrophoresis (right panels). Insert: quantification of apoptotic DNA fragmentation in U937 cells pre-incubated for indicated times with $16 \mathrm{nM}$ TPA, washed, then treated with $50 \mu \mathrm{M}$ etoposide for $6 \mathrm{~h}$. [One of two independent experiments is shown (mean \pm S.D. of triplicate samples)]. (B) Quantitative analysis by flow cytometry of phosphatidylserine externalization on the plasma membrane. Phosphatidylserine was identified by labeling the cells with annexin V-FITC (black symbols) and plasma membrane permeability was checked by colabeling the cells with propidium iodide (open symbols). (C) Cleavage of PARP, p27 ${ }^{\mathrm{Kip} 1}$ and RB proteins is visualized by Western blot analysis. Numbers are molecular weights in $\mathrm{kDa}$. *Indicates the cleavage products. Loading was checked by using an anti-human HSP70 monoclonal antibody. One of three independent experiments is shown 
Fas-ligand (Fas-L) is blocked upstream of this final common pathway. However, this final pathway remains functional and TPA-differentiated cells are highly sensitive to apoptosis induced by the protein synthesis inhibitor cycloheximide.

\section{Results}

\section{Etoposide-induced apoptosis is inhibited in U937 cells by TPA-mediated differentiation}

Exposure of U937 cells to 16 nM TPA induced a timedependent decrease of etoposide-induced apoptosis (Figure $1 \mathrm{~A}$, insert). After a $24 \mathrm{~h}$ exposure to $16 \mathrm{nM}$ TPA, more than $90 \%$ cells demonstrate an adherent phenotype, indicating their differentiation along a macrophagic pathway. At this time, cells that were not attached to the culture flask were removed. Attached cells (=TPA differentiated) were continuously treated for $1.5-24 \mathrm{~h}$ with $50 \mu \mathrm{M}$ etoposide and DNA fragmentation was quantified by filter elution assay (Figure $1 \mathrm{~A}$, left panel). These results were compared to those obtained in undifferentiated U937 cells treated in the same conditions. After a $6 \mathrm{~h}$ exposure to the drug, DNA was fragmented in about $80 \%$ undifferentiated cells whereas no DNA-fragmentation was observed in TPA-treated cells. This inhibition of etoposide-induced DNA fragmentation was confirmed by agarose gel electrophoresis (Figure 1A, right panels). Whereas a characteristic ladder of nucleosome-size DNA fragments was observed in undifferentiated cells exposed for $6 \mathrm{~h}$ to the drug, no DNA ladder was detectable in TPA-differentiated cells treated in the same conditions. Inhibition of etoposide-induced apoptosis in adherent TPAdifferentiated cells was further demonstrated by showing the inhibition of phosphatidylserine externalization on the outer plasma membrane leaflet, $6 \mathrm{~h}$ after the beginning of etoposide treatment (Figure 1B). At this time point, Annexin V-labeling in the presence of calcium ${ }^{31}$ was observed in $80 \%$ undifferentiated cells compared to $20 \%$ differentiated cells. After $24 \mathrm{~h}$ of drug exposure, some differentiated cells demonstrated Annexin V-labeling, suggesting that drug-induced apoptosis was delayed rather than completely inhibited in these cells. Therefore, we focused on the mechanisms that prevent cell death induced by a 6-h exposure to $50 \mu \mathrm{M}$ etoposide. At this time, the DNA repair enzyme PARP, the cyclin-dependent kinase inhibitor $\mathrm{p} 27^{\mathrm{Kip} 1}$ and the RB protein were cleaved in parental cells but not in differentiated cells (Figure 1C). In combination with the lack of characteristic morphological changes (data not shown), these data demonstrate that, in contrast to parental cells, TPA-differentiated U937 cells do not undergo apoptosis after a $6 \mathrm{~h}$ exposure to $50 \mu \mathrm{M}$ etoposide.

\section{Etoposide-induced apoptosis is inhibited upstream of procaspase-3 activation in TPA-differentiated U937 cells}

Caspase- 3 is a key protease involved in the protein cleavage associated with apoptosis. ${ }^{32}$ In undifferentiated U937 cells, etoposide exposure (50 $\mu \mathrm{M}, 6 \mathrm{~h})$ induced a decrease of the proenzyme form, procaspase-3, and its cleavage/activation into a p19 and a p17 fragments (Figure 2). These events were not observed in TPA-differentiated cells treated in the same conditions. We have shown recently that etoposide-induced apoptosis was associated with a decrease of procaspase-2L in undifferentiated cells. ${ }^{33}$ In the present study, we confirmed this result and showed that this event was not observed in etoposide-treated TPA-differentiated U937 cells (Figure 2). It has been reported that etoposide induced apoptosis was associated with procaspase-8 processing. ${ }^{34}$ TPA-mediated differentiation of $U 937$ cells prevented the decrease of procaspase- 8 expression induced by a $6 \mathrm{~h}$ exposure to etoposide (Figure 2).

\section{TPA-induced differentiation of U937 cells increases Bcl-xL expression and prevents etoposide-induced decrease of Mcl-1 protein level}

$\mathrm{Bcl}-2$ and $\mathrm{Bcl}-2$-related proteins have been demonstrated to modulate activation of procaspase- 3 and the caspase cascade. $^{27,35}$ Modulation of $\mathrm{Bcl}-2$-related protein levels has been associated with leukemic cell differentiation $20,27,36,37$ and cell treatment with cytotoxic drugs. ${ }^{38}$ Therefore, we examined the effect of TPA and etoposide exposure on $\mathrm{Bcl}-2$, $\mathrm{Bcl}-\mathrm{xL}, \mathrm{Mcl}-1$ and Bax expression in U937 cells. TPA induced a significant increase of $\mathrm{Bxl}-\mathrm{xL}$ and $\mathrm{Mcl}-1$ expression, as soon as $1 \mathrm{~h}$ after the beginning of U937 cell treatment. Bcl-xL remained increased in U937 cells examined after a 24-h exposure to TPA whereas $\mathrm{Mcl}-1$ expression returned to the

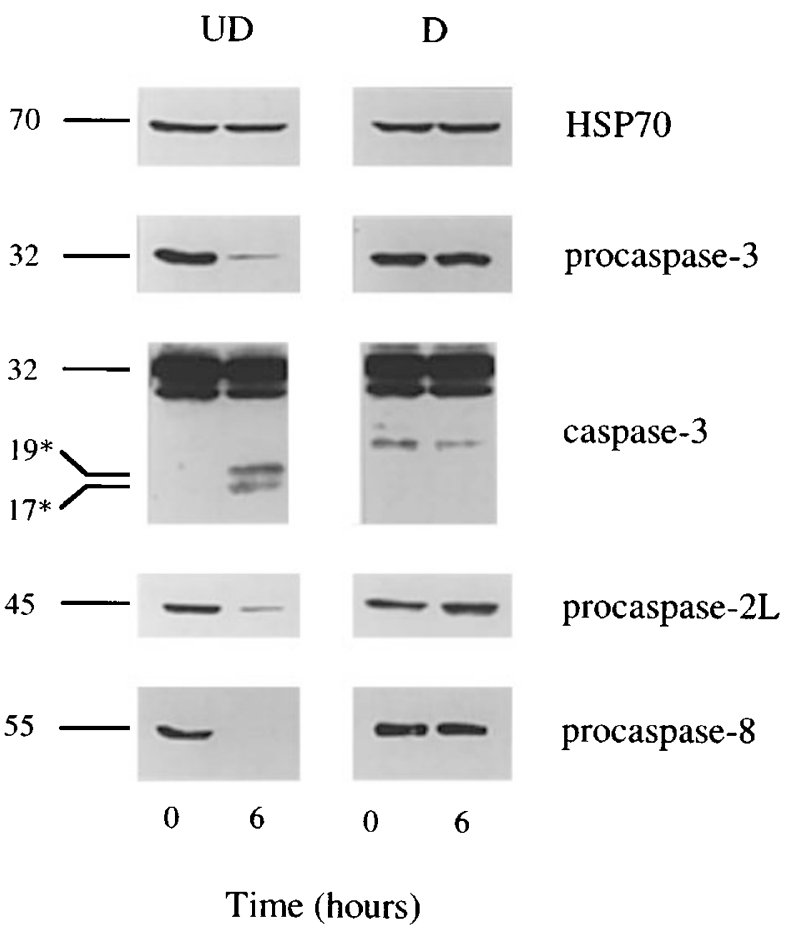

Figure 2 Western blot analysis of caspases. Analysis of procaspase-3 expression and its cleavage products and procaspases- $2 \mathrm{~L}$, and -8 expression in parental undifferentiated (UD) and TPA-differentiated (D) U937 cells treated with $50 \mu \mathrm{M}$ etoposide for $6 \mathrm{~h}$. Numbers are molecular weights in $\mathrm{kDa}$. *Indicates the cleavage products. Loading was checked by using an antihuman HSP70 monoclonal antibody. One of three independent experiments is shown 
basal level as the cells progress towards a differentiated phenotype. Other consequences of TPA-mediated differentiation included a slight decrease of $\mathrm{Bcl}-2$ and Bax expression (Figure 3A).

These four proteins were also monitored in parental and TPA-differentiated cells treated for $1.5-24 \mathrm{~h}$ with $50 \mu \mathrm{M}$ etoposide. Whereas the drug induced a progressive decrease in $\mathrm{Mcl}-1$ expression in parental cells, this effect was not observed in TPA-differentiated cells. In both parental and TPA-differentiated cells, the expression of the three other proteins was not modified during the first hours of etoposide exposure (Figure 3B). In undifferentiated cells, both anti-Bcl-2 and anti-Bax antibodies cross-reacted with a lower molecular weight protein that could correspond to a cleavage fragment ${ }^{39,40}$ after $24 \mathrm{~h}$ of etoposide treatment (Figure 3B)

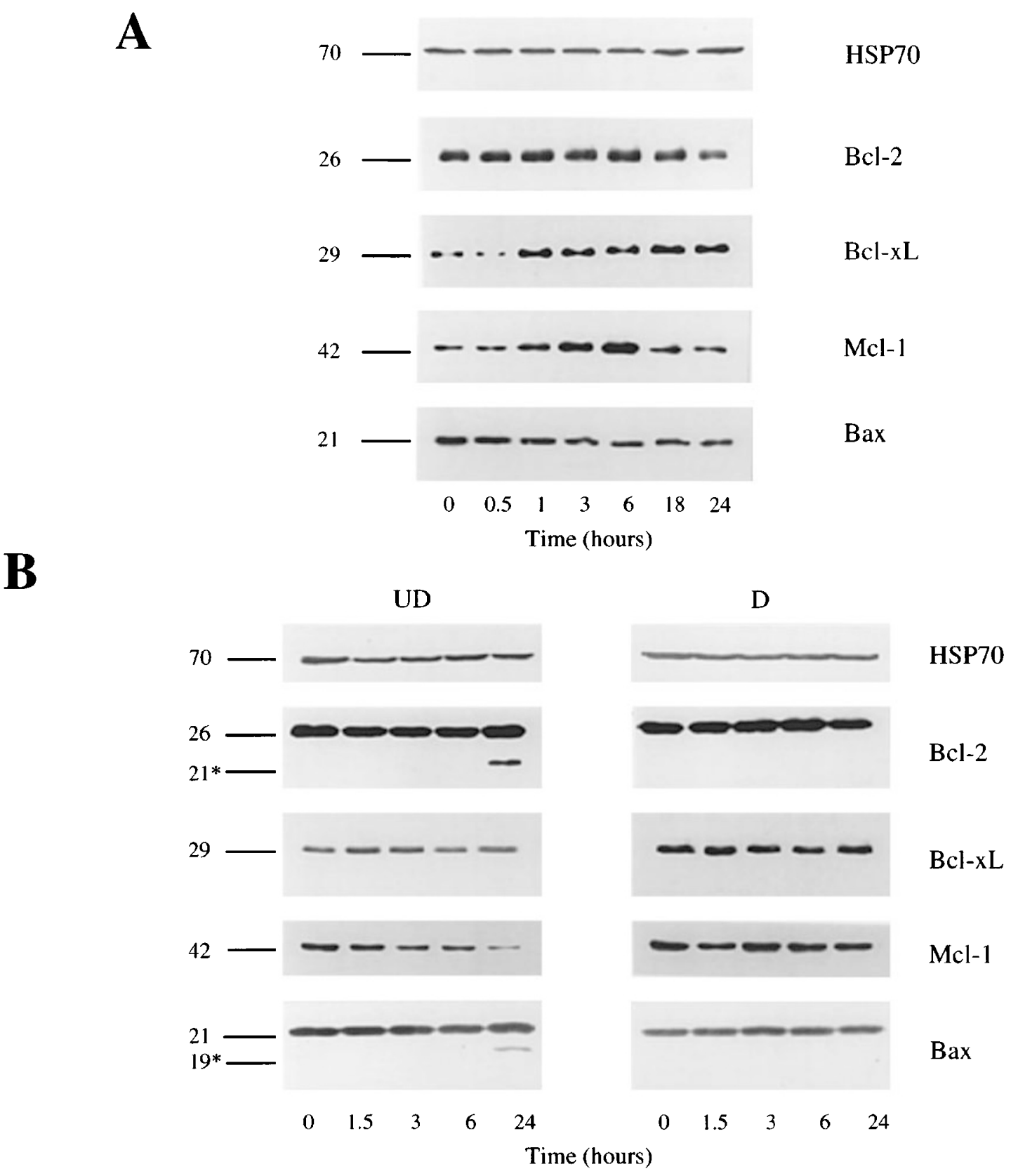

Figure 3 Western blot analysis of Bcl-2 and Bcl-2-related proteins. (A) Expression of Bcl-2, Bcl-xL, Mcl-1 and Bax in U937 cells incubated with $16 \mathrm{nM}$ TPA for indicated times. (B) Bcl-2, Bxl-xL, Mcl-1 and Bax expression in UD and D U937 cells treated with $50 \mu \mathrm{M}$ etoposide for indicated times. Numbers are molecular weights in $\mathrm{kDa}$. *Indicates a cleavage product. Loading was checked by using an anti-human HSP70 monoclonal antibody. One of three independent experiments is shown 
TPA-induced differentiation of U937 cells prevents cytochrome $c$ release from mitochondria induced by etoposide

Release of cytochrome $\mathrm{c}$ from the mitochondrial intermembrane space to the cytosol has been proposed as an early central event in apoptotic cell death. ${ }^{41}$ This event could be prevented by the antiapoptotic protein $\mathrm{Bcl}-2^{25,26}$ and $\mathrm{Bcl}-$ $\mathrm{XL}{ }^{28,29}$ Here, we confirmed that cytochrome $\mathrm{c}$ was released from mitochondria into the cytosol of U937 parental cells treated for $4 \mathrm{~h}$ with $50 \mu \mathrm{M}$ etoposide. Cytochrome $\mathrm{c}$ disappeared from the mitochondrial fraction and partitions with the S100 (cytosolic) fraction (Figure 4). Conversely, etoposide did not induce cytochrome $\mathrm{c}$ release in both $\mathrm{Bcl}-2$ transfected and TPA-differentiated U937 cells (Figure 4). These results indicated that the resistance of TPA-differentiated cells to etoposide induced apoptosis was associated with the blockade of cytochrome c release from the mitochondria.

\section{Adhesion of TPA-differentiated U937 cells to plastic is not responsible for the inhibition of etoposide-induced apoptosis}

Adhesion to the extracellular matrix has been demonstrated to inhibit apoptosis of epithelial cells. ${ }^{42}$ Since TPA-mediated differentiation of U937 floating cells induces their attachment to the plastic of culture flasks, we checked whether this adherent phenotype could be responsible for the resistance to etoposide-induced cell death. Therefore, U937 cells were induced to differentiate by TPA exposure in flasks whose plastic had been recovered with poly-HEMA, a polyacrylamide coating that prevents cell adhesion. Then, etoposideinduced apoptotic DNA fragmentation was quantified by filter elution assay. Exposure to $50 \mu \mathrm{M}$ etoposide for $6 \mathrm{~h}$ failed to induce apoptotic DNA fragmentation in TPA-differentiated cells, either adherent to the plastic of culture flasks or not, indicating that cell attachment to substrate is not responsible for the resistance of TPA-differentiating cells to etoposideinduced cell death (not shown).

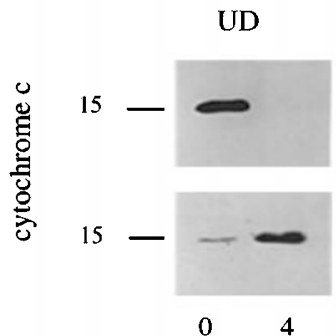

U4

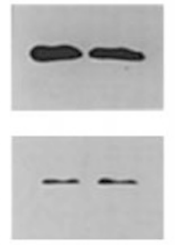

$0 \quad 4$

Time (hours)
D

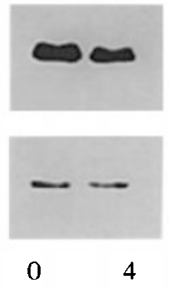

MIT

CYT

\section{TPA-differentiated cells are also resistant to vinblastine-induced and Fas-ligand-mediated apoptosis}

We have shown previously that the reduction of etoposideinduced topoisomerase II-mediated DNA breaks observed in TPA-differentiated HL-60 leukemic cells could not account for the strong inhibition of etoposide-induced apoptosis in these cells. ${ }^{10}$ To further exclude the role of changes in DNA breaks induced by etoposide in TPA-differentiated U937 cells, we checked whether these cells were resistant to apoptotic stimuli that do not induce DNA damage. Exposure of parental U937 cells to $10 \mathrm{ng} / \mathrm{ml}$ vinblastine for $24 \mathrm{~h}$ induced $80 \%$ DNA fragmentation, as measured by filter elution assay. In contrast, in TPA-differentiated cells, no vinblastine-induced DNA fragmentation was detected.

Exposure of U937 cells to soluble Fas-L induces about $60 \%$ DNA fragmentation after a 48-h exposure. TPAinduced differentiation upregulated Fas- $L$ expression (Figure 5A). This effect was observed $18-24 \mathrm{~h}$ after the beginning of cell treatment by TPA. Exposure to etoposide also increased Fas- $L$ expression in both undifferentiated and TPA-differentiated U937 cells (Figure 5B). Nevertheless, TPA-differentiated cells demonstrated partial resistance to Fas-L-mediated cell death (Figure 6A).

The decreased apoptotic DNA fragmentation observed in TPA-differentiated U937 cells treated with vinblastine or Fas-L was associated with an inhibition of PARP cleavage (not shown), caspase-3 p17 active fragment appearance and procaspase-3, procaspase-2L and procaspase-8 protein level decrease (Figure 6B).

$\mathbf{A}$

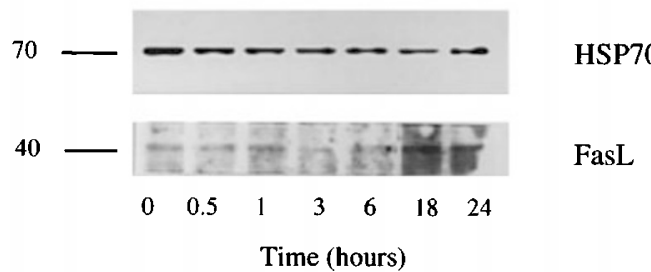

B

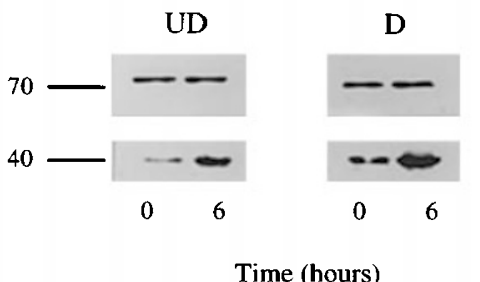

HSP70

FasL

Figure 5 Fas-ligand expression in parental and TPA-differentiated U937 cells. Western blot analysis of Fas-L expression in U937 cells exposed to $16 \mathrm{nM}$ TPA for indicated times (A) and undifferentiated (UD) or TPAdifferentiated (D) U937 cells exposed to $50 \mu \mathrm{M}$ etoposide for $6 \mathrm{~h}$ (B). (HSP70=checking of protein loading)
Figure 4 Mitochondrial changes in parental undifferentiated and TPAdifferentiated U937 cells. Western blot analysis of cytochrome c expression in mitochondrial (MIT) and cytosolic (CYT) fractions of parental undifferentiated (UD), Bcl-2-transfected (U4) and TPA-differentiated U937 cells (D) treated for $4 \mathrm{~h}$ with $50 \mu \mathrm{M}$ etoposide 
A

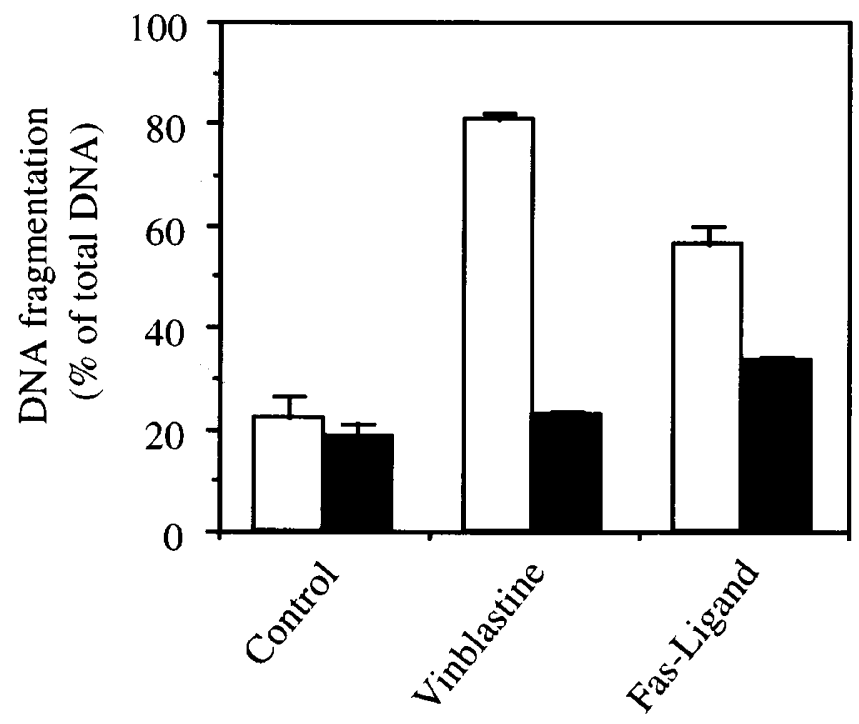

B

\section{Vinblastine}

UD

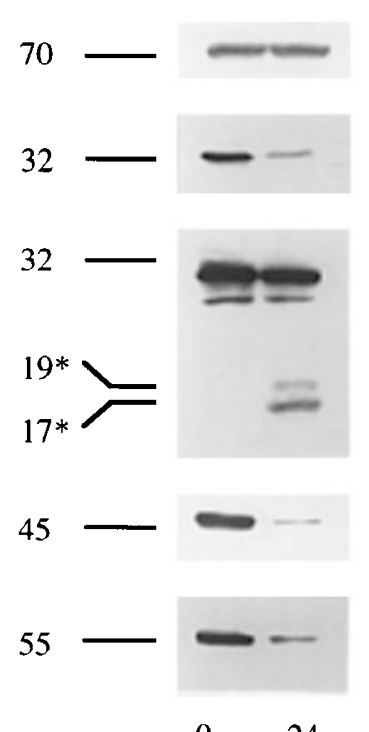

0

24

0

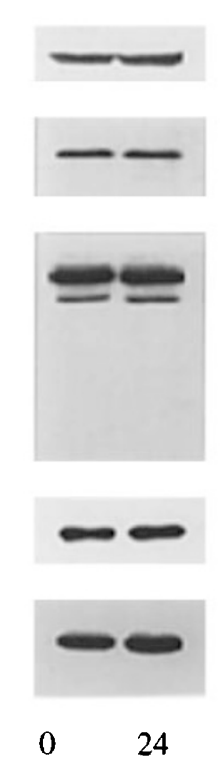

24

D
Fas-Ligand

UD

D

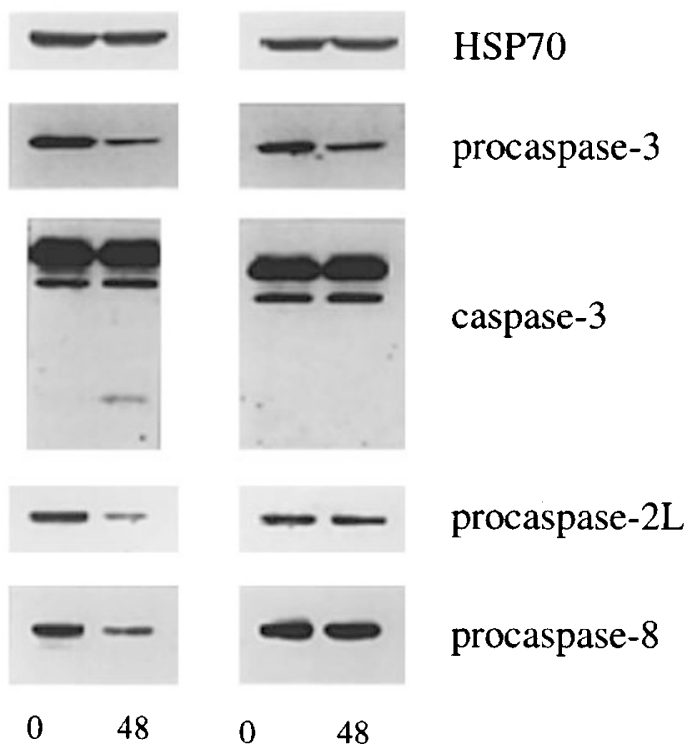

Time (hours)

Figure 6 Inhibition of vinblastine-induced and Fas-ligand-mediated apoptosis in TPA-differentiated cells. Parental undifferentiated (UD) and TPA-differentiated (D) U937 cells were treated for $24 \mathrm{~h}$ with $10 \mathrm{ng} / \mathrm{ml}$ vinblastine or for $48 \mathrm{~h}$ with 5 units soluble Fas-L produced by Neuro2A-transfected cells. (A) Apoptotic DNA fragmentation was quantified using filter elution assay in undifferentiated $(\square)$ and differentiated $(\boldsymbol{\square})$ cells. One of two independent experiments is shown (mean \pm S.D. of triplicate samples). (B) Western blot analysis of procaspase-3 expression and its cleavage fragments and procaspase-2L and -8 expression. Numbers are molecular weights in $\mathrm{kDa}$. *Indicates the cleavage products. Loading was checked by using an anti-human HSP70 monoclonal antibody 


\section{TPA-differentiated cells are highly sensitive to apoptosis triggered by cycloheximide}

We observed that TPA-differentiated cells were more sensitive than parental U937 cells to cell death induced by cycloheximide concentrations ranging from $0.5-10 \mu \mathrm{g} / \mathrm{ml}$ (Figure 7A). About 40\% DNA fragmentation was detected in TPA-differentiated cells, as measured by filter elution assay, after a 24-h exposure to $0.8 \mu \mathrm{g} / \mathrm{ml}$ cycloheximide (Figure 7A) whereas parental cells did not demonstrate apoptotic DNA fragmentation at this time. Cycloheximide-induced apoptosis of TPA-differentiated cells was associated with a cleavage of PARP, a cleavage/activation of procaspase- 3 and a decrease of procaspase-2L and procaspase- 8 protein levels, as demonstrated by Western blot. All these proteins remained unchanged in parental cells treated in the same conditions (Figure 7B). In these conditions, cycloheximide decreased
$\mathrm{Bcl}-\mathrm{xL}$ expression in TPA-differentiated cells, not in control cells whereas the protein level of $\mathrm{Bcl}-2$, Bax and $\mathrm{Mcl}-1$ remained unchanged in both control and TPA-differentiated U937 cells (Figure 7C). Lastly, at this concentration, cycloheximide specifically induced the release of cytochrome c from mitochondria in TPA-differentiated cells (Figure 7D).

\section{Discussion}

The present study confirms that the terminal differentiation of myeloid leukemic cells can induce a resistance phenotype to cytotoxic drug-induced apoptosis. ${ }^{10,11}$ Chemotherapeutic agents such as etoposide and vinblastine with distinct mechanisms of action failed to activate the final common pathway that leads to the execution phase of apoptosis in TPA-differentiated cells. These cells were also less sensitive to Fas-mediated apoptosis. Interestingly, the final apoptotic
A

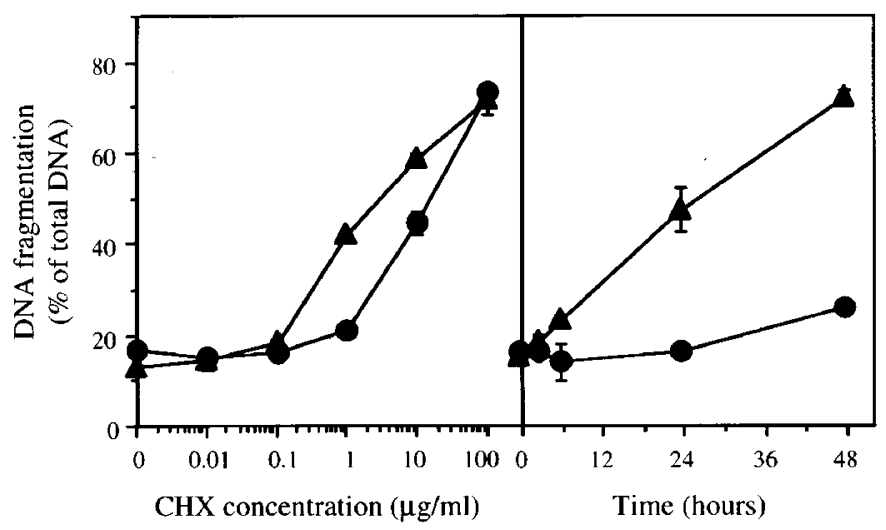

$\mathbf{C}$

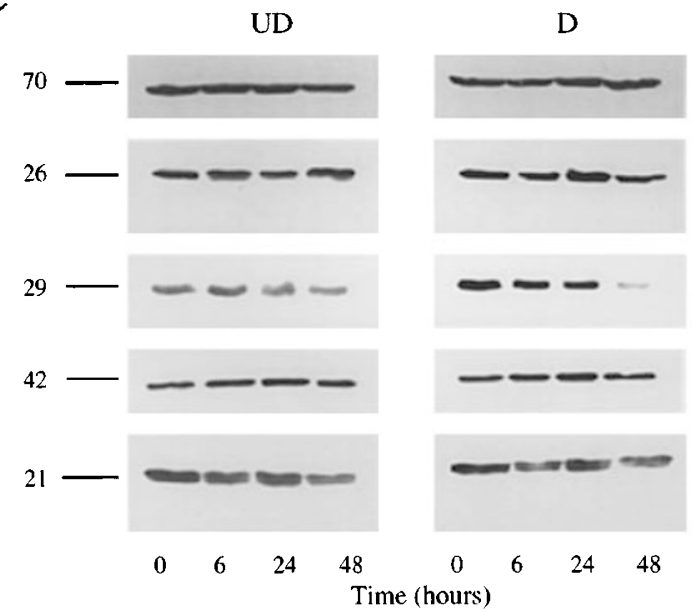

B
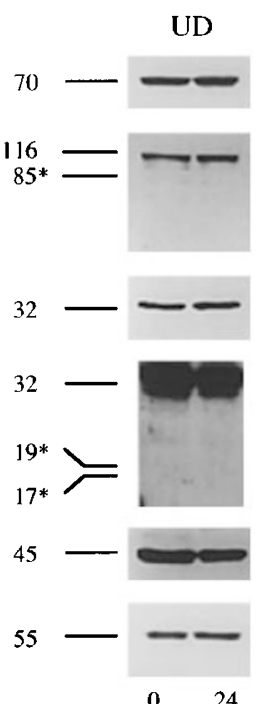

HSP70

Bcl-2

Bcl-xL

Mcl-1

Bax

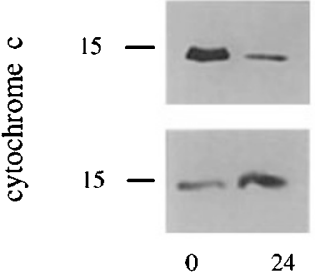

MIT

CYT

Figure 7 Sensitivity of TPA-differentiated cells to cycloheximide-induced apoptosis. (A) Parental undifferentiated (UD, $\mathbf{0})$ and TPA-differentiated (D, $\mathbf{A})$ U937 cells were treated with increasing concentrations of cycloheximide $(\mathrm{CHX})$ for $24 \mathrm{~h}$ (left panel) or with $0.8 \mu \mathrm{g} / \mathrm{ml}$ cycloheximide for indicated time (right panel). Apoptotic DNA fragmentation was quantified using filter elution assay. One of two independent experiments is shown (mean + S.D. of triplicate samples). (B) Western blot analysis of PARP cleavage, procaspase-3 expression and its cleavage fragments and procaspase-2L and -8 expression in UD and D U937 cells treated with $0.8 \mu \mathrm{g} / \mathrm{ml}$ cycloheximide for $24 \mathrm{~h}$. Numbers are molecular weights in $\mathrm{kDa}$. *Indicates the cleavage products. Loading was checked by using an antihuman HSP70 monoclonal antibody. (C) Bcl-2, Bcl-xL, Mcl-1 and Bax expression in UD and D U937 cells treated with $0.8 \mu \mathrm{g} / \mathrm{ml}$ cycloheximide for indicated times. Numbers are molecular weights in $\mathrm{kDa}$. One representative of three distinct experiments is shown. (D) Western blot analysis of cytochrome $\mathrm{c}$ expression in mitochondrial (MIT) and cytosolic (CYT) fractions in TPA-differentiated U937 cells treated with $0.8 \mu \mathrm{g} / \mathrm{ml}$ cycloheximide for $24 \mathrm{~h}$ 
pathway, that involves cytochrome c release from mitochondria to the cytosol and activation of caspases under the control of Bcl-2-related proteins, remained highly sensitive to low doses of cycloheximide in TPA-differentiated cells.

We and others ${ }^{10,43}$ have shown that leukemic cells induced to differentiate along various pathways ultimately die by apoptosis. Between acquisition of the differentiated phenotype and ultimate death, these cells demonstrate resistance to exogenous apoptotic stimuli. ${ }^{10}$ Inhibition of cell death pathways appears as a general feature of differentiation. ${ }^{27,44,45}$

TPA is a well-characterized activator of protein kinase $C$ (PKC), a key enzyme for transduction of extracellular and phospholipid-mediated signals as well as for tumor production. Short term exposure to TPA either induces apoptosis, e.g. in isolated thymocytes, ${ }^{46}$ or prevents apoptosis, e.g. in interleukin-3-deprived myeloid cells ${ }^{47}$ and in U937 cells treated with TNF $\alpha$, calphostin $\mathrm{C}^{48}$ or etoposide (this study). Additional evidence for a role of PKC in apoptosis is that several isoenzymes of PKC can be activated during the cell death process and that many PKC activators such as staurosporine and its 7-hydroxy derivative, UCN-01, are potent inducers of apoptosis. ${ }^{49}$ However, the functional significance of the activation of PKC isoenzymes in cells undergoing apoptosis remains poorly understood.

The short-term effects of TPA exposure might be distinguished from those related to acquisition differentiated phenotype. Analysis of TPA-resistant clones of U937 cells has demonstrated that the differentiation process involved several events downstream of PKC isoforms activation and translocation. ${ }^{50}$ Monocytic differentiation of U937 cells induced by 1,25-dihydroxyvitamin $D_{3}$ also protects cells from apoptosis induced by chemotherapeutic drugs $^{27}$ and Fas agonists. ${ }^{51}$ Differentiation of myocytes also induces resistance to growth factor deprivationinduced cell death. ${ }^{44}$ Inhibition of drug-induced and Fasmediated apoptosis, as well as sensitization to cycloheximide, that are reported in the present study, are rather a consequence of the differentiation phenotype than a direct effect of PKC activation. ${ }^{10}$

The phenotype of TPA-differentiated U937 cells includes their attachment to the culture flasks. Extracellular matrix was shown to regulate apoptosis in many cell types, including epithelial cells, endothelial cells and muscle cells through an integrin-dependent negative regulation of caspases involving MEKK-1 activation. ${ }^{42,52}$ Here, we show that the adherent phenotype of TPA-differentiated cells is not necessary for their spontaneous survival, nor is it responsible for their resistance to etoposide-induced apoptosis. In addition, both attached and unattached differentiated cells are equally sensitive to cycloheximideinduced cell death (not shown). Thus, this attached phenotype is not reponsible for the modulation of apoptosis in TPA-differentiated U937 cells.

We have demonstrated the role of a DEVD-sensitive caspase in the proteolytic cascade that leads to PARP and $\mathrm{p} 27^{\mathrm{Kip} 1}$ cleavage in etoposide-treated U937 cells, ${ }^{15}$ (Eymin et al, submitted). One of the caspases which are sensitive to the tetrapeptide DEVD is a procaspase- 3 . $^{32}$
This cytosolic protein normally exists as a $32 \mathrm{kDa}$ inactive precursor. In etoposide-treated U937 parental cells, procaspase-3 is cleaved proteolytically at aspartic residues to generate the $17 \mathrm{kDa}$ fragment involved in the formation of the active heterodimeric caspase. Here, we show that TPA-induced differentiation prevents the activation of procaspase- 3 induced by etoposide, vinblastine and Fas-L. Recent studies have demonstrated that procaspase-3 processing could be triggered by the release of cytochrome $c$ from mitochondria. ${ }^{30}$ This release is inhibited in TPA-differentiated U937 cells treated with etoposide. Nevertheless, the ability of cycloheximide to induce cytochrome $c$ release and procaspase-3 activation in TPA-differentiated cells clearly indicates that this pathway remains functional. Altogether, these results indicate that drug-induced and Fas-mediated apoptotic pathways are inhibited upstream of procaspase-3 activation by a blockage of cytochrome c release from mitochondria in TPA-differentiated cells.

The molecular ordering of the proteolytic cascade that leads to apoptosis remains poorly understood. Both procaspase-2 $\mathrm{L}^{53}$ and procaspase- $8^{34}$ are processed in cells undergoing apoptosis. Whether these procaspases are activated upstream or downstream of procaspase-3 and whether their activation requires the mitochondrial release of pro-apoptotic factors or not could depend on the apoptotic stimulus. ${ }^{53,54}$ We show here that TPA-mediated differentiation of U937 cells prevents the activation of both procaspase-2L and procaspase- 8 by cytotoxic drugs and Fas-L.

$\mathrm{Bcl}-2$ and $\mathrm{Bcl}-2$-related antiapoptotic proteins such as $\mathrm{Bcl}-\mathrm{xL}$ and $\mathrm{Mcl}-1$ function upstream of procaspase-3. ${ }^{27,35}$ Both $\mathrm{Bcl}-2$ and $\mathrm{Bcl}-\mathrm{xL}$ were shown to prevent the release of cytochrome $c$ from mitochondria $25,26,28,29$ whereas the proapoptotic member Bax causes death through direct mitochondrial effects. ${ }^{55}$ U937 exposure to TPA rapidly increased $\mathrm{Mcl}-1$ and $\mathrm{Bxl}-\mathrm{xL}$ expression. $\mathrm{Mcl}-1$ returned to the basal level whereas $\mathrm{Bcl}-\mathrm{xL}$ remained elevated as the cells acquired their differentiated phenotype. These results suggest that $\mathrm{Mcl}-1$ could be involved only in the short term effects of TPA whereas $\mathrm{Bcl}-\mathrm{xL}$ could play a role in both its short and long term effects. Bcl-xL expression remained unchanged upon etoposide treatment whereas it decreased upon cycloheximide exposure. The specific ability of cycloheximide to down-regulate $\mathrm{Bcl}-\mathrm{xL}$ protein level in TPA-differentiated cells could contribute to cytochrome c release from mitochondria, activation of caspases and apoptosis. A similar decrease in $\mathrm{Bcl}-\mathrm{xL}$ expression was involved in apoptosis induced by growth-factor deprivation in leukemic cells. ${ }^{56} \mathrm{Mcl}-1$ expression remains stable when TPA-differentiated cells undergoing cycloheximide-induced apoptosis whereas its expression decreases in undifferentiated cells undergoing etoposide-induced cell death. These observations suggest that modulation of $\mathrm{Bcl}-2-$ related proteins associated with apoptosis depends on both the apoptotic stimulus and the level of differentiation of the target cell.

TPA-induced differentiation of U937 cells is associated with an increased expression of Fas-ligand. Whether interaction of this ligand with its receptor Fas plays a role 
in drug-induced cell death ${ }^{57}$ or not ${ }^{58}$ remains a controversial issue. We confirm that etoposide increases Fas-ligand expression in undifferentiated U937 cells $^{59}$ and demonstrate that TPA-mediated differentiation does not prevent this upregulation. However, apoptosis induced by interaction of Fas-ligand with its receptor is partly inhibited by the differentiation process.

In conclusion, drug-induced and Fas-mediated apoptotic pathways are blocked upstream of the mitochondrial release of cytochrome $\mathrm{c}$ and activation of caspase-2L, caspase-3 and caspase-8 in TPA-differentiated U937 cells. The ability of low doses cycloheximide to trigger these events in differentiated cells indicates that (1) the final pathway common to many apoptotic stimuli remains functional in these cells, and (2) undifferentiated and differentiated cells are sensitive to distinct apoptotic stimuli. These observations might be taken into account in therapeutic strategies combining chemotherapy and differentiating agents.

\section{Materials and Methods}

\section{Drugs and chemical reagents}

Etoposide (VP-16), cycloheximide (CHX) and 12-O-tetradecanoylphorbol 13-acetate (TPA) were obtained from Sigma-Aldrich laboratories (St Quentin Fallavier, France). Stock solutions were prepared by diluting these reagents in dimethyl sulfoxide (DMSO) and stored at $-20^{\circ} \mathrm{C}$. Further dilutions were made in culture medium just before use. The final concentration of DMSO in culture medium did not exceed $0.1 \%(\mathrm{v} / \mathrm{v})$, which was non-toxic to the cells. $\left[2-{ }^{14} \mathrm{C}\right]$-thymidine (56 $\mathrm{mCi} / \mathrm{mM}$ ) was obtained from Amersham (Les Ulis, France). All other chemicals were of reagent grade and purchased from local sources.

\section{Murine Fas-Ligand (Fas-L) production}

Murine Fas-L was collected from FasL-transfected Neuro2A murine cells supernatant (kindly provided by $\operatorname{Dr}$ A. Fontana, Zurich, Switzerland) after 2 days of culture in Dulbecco-MEM medium (Biowhittaker, Fontenay-sous-bois, France) containing a $1 \%$ fetal bovine serum. This supernatant was concentrated 100 -fold using the ultrafree-15 centrifugal filter device biomax-10K membrane (Millipore, Molsheim, France). Control supernatant from mock-transfected cells obtained in the same conditions did not induce any cytotoxicity of U937 cells. One arbitrary unit of Fas-L or mock supernatant was defined as $1 \mu \mathrm{L}$ of a 100 -fold concentrated supernatant of Neuro2A cells that had been confluent for $48 \mathrm{~h}$. A unique pool of Fas-L or mock supernatant was used throughout the present study.

\section{Antibodies}

Antibodies used included anti-human HSP70 (StressGen, Victoria, Canada), retinoblastoma protein (RB), procaspase-2, procaspase-8, cytochrome c (Pharmingen, San Diego, CA), p27 ${ }^{\text {Kip1 }}$, procaspase-3, Bcl-xL (Transduction Laboratories, Lexington, KY, USA), Bcl-2 (Dako, Trappes, France) and Bax (Immunotech, Marseille, France) mouse monoclonal antibodies and anti-human Mcl-1 and Fas-L (clone N20) rabbit polyclonal antibodies (Santa Cruz Biotechnology, California, USA). The $116 \mathrm{kDa}$ native PARP protein and its $85 \mathrm{kDa}$ cleavage product were detected using anti-human PARP rabbit polyclonal antibody (Boehringer-Mannheim, Germany). A rabbit polyclonal antiapopain/caspase-3-p17 antibody (kindly provided by Dr D. Nicholson, Merck Co, Quebec, Canada) that recognizes both caspases-3 proenzyme and its $\mathrm{p} 19$ and $\mathrm{p} 17$ subunits $^{60}$ was used to detect procaspase-3 activation in apoptotic U937 cells.

\section{Cell culture}

The human leukemic U937 cells were grown in suspension in RPMI 1640 medium (BioWhittaker) supplemented with $10 \%(\mathrm{v} / \mathrm{v})$ heatinactivated fetal bovine serum (FBS) and $2 \mathrm{mM}$ L-glutamine in an atmosphere of $95 \%$ air and $5 \% \mathrm{CO}_{2}$ at $37^{\circ} \mathrm{C}$. Cell viability was determined using the trypan blue exclusion test. To ensure exponential growth, cells were resuspended at a density of $0.5 \times 10^{6}$ cells $/ \mathrm{ml}$ in fresh medium $24 \mathrm{~h}$ before each treatment. To induce differentiation, cells were cultured in the presence of $16 \mathrm{nM}$ TPA for $24 \mathrm{~h}$. Then, adherent TPA-differentiated cells were treated in TPA-free medium. After treatment, adherent cells were harvested using a cell scraper. To cope with cellular adhesion influence, cells were induced to differentiate by TPA in flasks that were covered with $0.6 \%$ PolyHEMA [poly(2-hydroxyethyl methacrylate), Sigma] in order to prevent their adhesion.

\section{Quantification of DNA fragmentation}

DNA fragmentation was measured using a previously reported filter elution assay. ${ }^{61}$ Briefly, exponentially growing cells were incubated with $0.02 \mu \mathrm{Ci} / \mathrm{ml}$ of $\left[2-{ }^{14} \mathrm{C}\right]$-thymidine and cultured at $37^{\circ} \mathrm{C}$ for 2 days. Then, cells were chased in isotope-free medium overnight, resuspended in fresh medium and treated with different agents before or after TPA-treatment. Approximately $1.0 \times 10^{6}$ treated or untreated labeled cells were loaded onto a protein absorbing filter (Polyvinylidene fluorure filters, $0.65 \mu \mathrm{m}$ pore size, $25 \mathrm{~mm}$ diameter; Durapore membrane, Millipore). Cells were then washed once with ice-cold phosphate-buffered saline (PBS) and subsequently lysed in $0.2 \%$ sodium sarkosyl, $2 \mathrm{M} \mathrm{NaCl}, 0.04 \mathrm{M}$ EDTA, pH 10.0. Filters were washed with $0.02 \mathrm{M}$ EDTA, pH 10.0. DNA was depurinated by incubation of filters in $1 \mathrm{M} \mathrm{HCl}$ at $65^{\circ} \mathrm{C}$ for $45 \mathrm{~min}$, then released from the filters with $0.4 \mathrm{M} \mathrm{NaOH}$ for $45 \mathrm{~min}$ at room temperature. Radioactivity was counted by liquid scintillation spectrometry in each fraction (wash, lysis, EDTA wash and filter).

\section{Analysis of DNA fragmentation by agarose gel electrophoresis}

Cellular DNA was extracted by a salting-out procedure as described previously. ${ }^{62}$ Electrophoresis was performed in $1.8 \%$ agarose gel in Tris-borate-EDTA buffer ( $\mathrm{pH} \mathrm{8.0)}$ ) at $20 \mathrm{~V}$ for $14 \mathrm{~h}$. After electrophoresis, DNA was visualized by ethidium bromide staining.

\section{Western blot analysis}

After treatment, cells were washed twice in PBS, lysed in Ripa buffer (150 mM NaCl, $50 \mathrm{mM}$ Tris- $\mathrm{HCl}, \mathrm{pH} 8.0,0.1 \% \mathrm{Na}-\mathrm{SDS}, 0.5 \% \mathrm{Na}-$ desoxycholate) in the presence of protease inhibitors $[0.1 \mathrm{mM}$ phenylmethylsulfonylfluoride (PMSF), $2.5 \mu \mathrm{g} / \mathrm{ml}$ pepstatin, $10 \mu \mathrm{g} / \mathrm{ml}$ aprotinin, $2.5 \mu \mathrm{g} / \mathrm{ml}$ trypsine inhibitor, $5 \mu \mathrm{g} / \mathrm{ml}$ leupeptine] for $30 \mathrm{~min}$ and then centrifuged $(20 \mathrm{~min}, 15000 \times \mathrm{g}$. Fifty $\mu \mathrm{g}$ proteins of supernatants were incubated in loading buffer $(125 \mathrm{mM}$ Tris- $\mathrm{HCl}, \mathrm{pH}$ $6.8,10 \% \beta$-mercapto-ethanol, $4.6 \%$ SDS, $20 \%$ glycerol and $0.003 \%$ 
bromophenol blue), separated by sodium dodecyl sulfate polyacrylamide gel (SDS-PAGE) and electroblotted to PVDF membrane (BioRad, Ivry sur Seine, France). After blocking non-specific binding sites overnight by $5 \%$ nonfat milk in TPBS (PBS, Tween $200.1 \%$ ), the membrane was incubated for $2 \mathrm{~h}$ at room temperature with primary antibody. After two washes in TPBS, the membrane was incubated with horseradish peroxidase-conjugated goat anti-mouse or anti-rabbit antibodies (Jackson ImmunResearch Laboratories, West Grove, PE) for $30 \mathrm{~min}$ at room temperature and then washed twice in TBPS. Immunoblot was revealed using enhanced chemioluminescence detection kit (Amersham, Les Ulis, France) by autoradiography. For the PARP cleavage analysis, cells were lysed in boiling lysis solution ( $1 \%$ SDS, $1 \mathrm{mM}$ Na-vanadate, $10 \mathrm{mM}$ Tris $\mathrm{pH} 7.4$ ) in the presence of protease inhibitors as described above. The viscosity of the samples is reduced by several passages through a 26 gauge needle.

\section{Analysis of apoptosis-associated membrane alterations}

Exposure of phosphatidylserine on the outer plasma membrane leaflet was determined by the use of the annexin V-FITC kit (Bioproducts, Boehringer Ingelheim, Heidelberg). Briefly, after treatment, $10^{6}$ cells were incubated in labeled buffer (10 mM HEPES/ $\mathrm{NaOH}, \mathrm{pH} 7.4$, $140 \mathrm{mM} \mathrm{NaCl}, 2.5 \mathrm{mM} \mathrm{CaCl}_{2}$ ) in the presence of both annexin V-FITC $1 \mu \mathrm{g} / \mathrm{ml}$ and propidium iodide $1 \mu \mathrm{g} / \mathrm{ml}$ for $10 \mathrm{~min}$ in the dark. Cells were washed once in PBS and resuspended in $1 \mathrm{ml}$ labeled buffer. Analysis was performed using a FACScan flow cytometer (Becton Dickinson, Le Pont de Claix, France).

\section{Cell fractionation}

Mitochondrial and cytosolic (S100) fractions for cytochrome c release studies were prepared by resuspending the cells in ice cold buffer $A$ [sucrose $250 \mathrm{mM}$ HEPES $20 \mathrm{mM}, \mathrm{KCl} 10 \mathrm{mM}, \mathrm{MgCl}_{2} 1.5 \mathrm{mM}$, EDTA $1 \mathrm{mM}$, EGTA $1 \mathrm{M}$, DTT $1 \mathrm{mM}$, PMSF $17 \mu \mathrm{g} / \mathrm{ml}$, aprotinin $8 \mu \mathrm{g} / \mathrm{ml}$, leupeptine $2 \mu \mathrm{g} / \mathrm{ml}(\mathrm{pH} 7.4)$ before passing them through an ice-cold cell homogenizer. Unlysed cells and nuclei were pelleted via a $10 \mathrm{~min}$ $750 \times g$ spin. The supernatant was centrifuged at $10000 \times g$ for $25 \mathrm{~min}$, and the resulting mitochondria pellet was resuspended in buffer $A$ and frozen at $-80^{\circ} \mathrm{C}$. The supernatant of the $10000 \times g$ spin was further centrifuged at $100000 \times g$ for $1 \mathrm{~h}$ and the resulting supernatant (S100 fraction) was frozen at $-80^{\circ} \mathrm{C}$.

\section{Acknowledgements}

We are grateful to A. Fontana (Zurich University Hospital) for Fas-ligand transfected Neuro-2A cells and D.W. Nicholson (Merck Co, Toronto, Canada) for the anti-caspase-3 antibody. This work was supported by grants from INSERM, the Ligue Nationale Contre le Cancer (Bourgogne, Saône et Loire, Nièvre and Yonne Committees), the Association pour la Recherche contre le Cancer (ARC\#4075) and the Conseil Régional de Bourgogne.

\section{References}

1. Rovera G, Santoli D and Damsky C (1979) Human promyelocytic leukemia cells in culture differentiate into macrophage-like cells when treated with phorbol diester. Proc. Natl. Acad. Sci. USA 76: 2779-2783

2. Aihara H, Asaoka Y, Yoshida K and Nishizuka Y (1991) Substained activation of protein kinase $\mathrm{C}$ is essential to $\mathrm{HL}-60$ cell differentiation to macrophage. Proc. Natl. Acad. Sci. USA 88: 11062-11066
3. Holt JT, Redner RL and Nienhuis AW (1988) An oligomer complementary to cmyc mRNA inhibits proliferation of HL-60 promyelocytic cells and induces differentiation. Mol. Cell. Biol. 8: 963-973

4. Hass R, Gunji H, Hirano M, Weichselbaum R and Kufe D (1993) Phorbol esterinduced monocytic differentiation is associated with $\mathrm{G}_{2}$ delay and downregulation of cdc25 expression. Cell Growth Differ. 4: 159-166

5. Sariban E, Mitchell T and Kufe D (1985) Expression of the c-fms proto-oncogene during human monocytic differentiation. Nature (Lond.) 316: 64-66

6. Sherman ML, Stone RM, Datta R, Bernstein SH and Kufe DW (1990) Transcriptional and post-transcriptional regulation of $c$-jun expression during monocytic differentiation of human myeloid leukemic cells. J. Biol. Chem. 265: $3320-3323$

7. Szabo E, Preis LH, Brown PH and Birrer MJ (1991) The role of jun and fos in 12-Otetradecanoylphorbol-13-acetate induced hemopoietic differentiation. Cell Growth Differ. 10: 475-482

8. Collins SJ (1987) The HL-60 promyelocytic leukemia cell line: proliferation, differentiation, and cellular oncogene expression. Blood 70: 1233-1244

9. Solary E, Bertrand R and Pommier Y (1994) Apoptosis of human leukemic HL60 cells induced to differentiate by phorbol ester treatment. Leukemia 8: 792 797

10. Solary E, Bertrand R, Kohn K and Pommier Y (1993) Differential induction of apoptosis in undifferentiated and differentiated HL60 cells by DNA topoisomerase I and II inhibitors. Blood 81: 1359-1368

11. Xu HM, Tepper CG, Jones JB, Fernandez CE and Studzinski GP (1993) 1,25Dihydroxyvitamin D3 protecs HL-60 cells against apoptotis but down-regulates the expression of the bcl-2 gene. Exp. Cell. Res. 209: 367-374

12. Thompson CB (1995) Apoptosis in the pathogenesis and treatment of disease. Science 267: 1456-1462

13. Golstein $P$ (1997) Controlling cell death. Science 275: 1081-1082

14. Hale AJ, Smith CA, Sutherland LC, Stoneman VEA, Longthorne VL, Culhane AC and Williams GT (1996) Apoptosis: molecular regulation of cell death. Eur. J. Biochem. 237: 1-26

15. Dubrez L, Savoy I, Hamman A and Solary E (1996) Pivotal role of a DEVDsensitive step in etoposide-induced and Fas-mediated apoptotic pathways. EMBO J. 15: $5504-5512$

16. Solary E, Eymin B, Droin N, Haugg M (1998) Proteases, proteolysis, and apoptosis. Cell. Biol. Tox. 14: 121-132

17. Salvesen GS and Dixit VM (1997) Caspases: intracellular signaling by proteolysis. Cell 91: 443-446

18. Kaufmann SH, Desnoyers S, Ottaviano Y, Davidson NE and Poirier GG (1993) Specific proteolytic cleavage of poly(ADP-ribose)polymerase: an early marker of chemotherapy-induced apoptosis. Cancer Res. 53: 3976-3985

19. Chen WD, Otterson GA, Lipkowitz S, Khleif SN, Coxon AB and Kaye FJ (1997) Apoptosis is associated with cleavage of a $5 \mathrm{kDafragment}$ from $\mathrm{RB}$ which mimics dephosphorylation and modulates E2F binding. Oncogene 14: 1243-1248

20. Kozopas KM, Yang T, Buchan HL, Zhou P and Craig RW (1993) MCL1, a gene expressed in programmed myeloid cell differentiation, has sequence similarity to BCL2. Proc. Natl. Acad. Sci. USA 90: 3516-3520

21. Zhou P, Qian L, Kozopas KM and Craig RW (1997) Mcl-1, a Bcl-2 family member, delays the death of hematopoietic cells under a variety of apoptosis-inducing conditions. Blood 89: 630-643

22. Reed JC (1997a) Double identity for proteins of the Bcl-2 family. Nature 387: $773-776$

23. Zamzami N, Susin SA, Marchetti P, Hirsch T, Gomez-Monterrey I, Castedo Mand Kroemer G (1997) Mitochondrial control of nuclear apoptosis. J. Exp. Med. 183: $1533-1544$

24. Marchetti P, Susin SA, Decaudin D, Gamen S, Castedo M, Hirsch T, Zamzami N, Naval J, Senik A and Kroemer G (1996) Apoptosis-associated derangement of mitochondrial function in cells lacking mitochondrial DNA. Cancer Res. 56: 2033-2038

25. Yang J, Liu X, Bhalla K, Kim CN, Ibrado AM, Cai J, Peng TI, Jones DP and Wang X (1997) Prevention of apoptosis by bcl-2: release of cytochrome $\mathrm{C}$ from mitochondria blocked. Science 275: 1129-1132

26. Kluck RM, Bossy-Wetzel E, Green DR and Newmeyer DD (1997) The release of cytochrome c from mitochondria: a primary site for $\mathrm{Bcl}-2$ regulation of apoptosis. Science 275: $1132-1136$

27. Wang X and Studzinski GP (1997) Antiapoptotic action of 1,25-dihydroxyvitamin D3 is associated with increased mitochondrial MCL-1 and RAF-1 proteins and reduced release of cytochrome c. Exp. Cell. Res. 235: 210-217 
28. Vander Heiden MG, Chandel NS, Williamson EK, Schumacker PT and Thompson CB (1997) Bcl- $x_{\mathrm{L}}$ regulates the membrane potential and volume homeostasis of mitochondria. Cell 91: 627-637

29. Kharbanda S, Pandey P, Schofield L, Israels S, Roncinske R, Yoshida K, Bharti A, Yuan ZM, Saxena S, Weichselbaum R, Nalin C and Kufe D (1997) Role for Bcl$\mathrm{xL}$ as an inhibitor of cytosolic cytochrome $\mathrm{c}$ accumulation in DNA damageinduced apoptosis. Proc. Natl. Acad. Sci. USA 94: 6939-6942

30. Li P, Nijhawan D, Budihardjo I, Srinivasula SM, Ahmad M, Alnemri ES and Wang X (1997a) Cytochrome $c$ and dATP-dependent formation of Apaf-1/caspase- 9 complex initiates an apoptotic protease cascade. Cell 91: 479-489

31. Koopman G, Reutelingsperger CPM, Kuijten GAM, Keehnen RMJ, Pals ST and Van Oers MHJ (1994) Annexin V for flow cytometry detection of phosphatidylserine expression on B cells undergoing apoptosis. Blood 84: $1415-1420$

32. Nicholson DW, Ali A, Thornberry NA, Vaillancourt JP, Ding CK, Gallant M, Gareau Y, Griffin PR, Labelle M, Lazebnik YA, Munday NA, Raju SM, Smulson ME, Yamin T, Yu VL and Miller DK (1995) Identification and inhibition of the ICE/ CED-3 protease necessary for mammalian apoptosis. Nature 376: $37-43$

33. Droin N, Dubrez L, Eymin B, Renvoizé C, Bréard J, Dimanche-Boitrel MT and Solary $E$ (1998) Upregulation of CASP genes in human tumor cells undergoing etoposide-induced apoptosis. Oncogene 16: 2885-2894

34. Cock JG, de Vries E, Williams GT and Borst J (1998) The anticancer drug etoposide can induce caspase-8 processing and apoptosis in the absence of CD95 receptor-ligand interaction. Apoptosis 3: 17-25

35. Chinnaiyan AM, Orth K, O'Rourke K, Duan H, Poirier GG and Dixit VM (1996) Molecular ordering of the cell death pathway. $\mathrm{Bcl}-2$ and $\mathrm{Bcl}-\mathrm{x}_{\mathrm{L}}$ function upstream of the CED-3-like apoptotic proteases. J. Biol. Chem. 271: 4573-4576

36. Delia D, Aiello A, Soligo D, Fontanella E, Melani C, Pezzella F, Pierotti MA and Della Porta G (1992) bcl-2 proto-oncogene expression in normal and neoplastic human myeloid cells. Blood 79: 1291-1298

37. Chatterjee D, Han Z, Mendoza J, Goodlick L, Hendrickson EA, Pantazis P and Wyche JH (1997) Monocytic differentiation of HL-60 promyelocytic leukemia cells correlates with the induction of Bcl-xL. Cell Growth Differ. 8: 1083-1089

38. Tu Y, Xu FH, Liu J, Vescio R, Berenson J, Fady C and Lichtenstein A (1996) Upregulated expression of $B C L-2$ in multiple myeloma cells induced by exposure to doxorubicin, etoposide, and hydrogen peroxide. Blood 88: 1805-1812

39. Fugita $\mathrm{N}$ and Tsuruo T (1998) Involvement of $\mathrm{Bcl}-2$ cleavage in the acceleration of VP-16 induced U937 cell apoptosis. Biochem. Biophys. Res. Commun. 246 $484-488$

40. Kobayashi T, Ruan S, Jabbur JR, Consoli U, Clodi K, Shiku H, Owen-Schaub LB, Andreeff M, Reed JC and Zhang W (1998) Differential p53 phosphorylation and activation of apoptosis-promoting genes Bax and Fas/APO-1 by irradiation and ara-C treatment. Cell Death Diff. 5: 584-591

41. Reed JC (1997b) Cytochrome c: can't live with it-can't live without it. Cell 91: 559-562

42. Cardone MH, Salvesen GS, Widmann C, Johnson G and Frisch SM (1997) The regulation of anoikis: MEKK-1 activation requires cleavage by caspases. Cell 90: $315-323$

43. Martin SJ, Bradley JG and Cotter TG (1990) HL-60 cells induced to differentiate towards neutrophils subsequently die via apoptosis. Clin. Exp. Immunol. 79: $448-453$

44. Wang J and Walsh K (1996) Resistance to apoptosis conferred by cdk inhibitors during myocyte differentiation. Science 273: 359-361

45. Wu YL, Jiang XR, Lillington DM, Allen PD, Newland AC and Kelsey SM (1998) 1,25-Dihydroxyvitamin D3 protects human leukemic cells from tumor necrosis factor-induced apoptosis via inactivation of cytosolic phospholipase A2. Cancer Res. 58: $633-640$
46. Kizaki H, Tadakuma T, Odaka C, Muramatsu J and Ishimura Y (1989) Activation of a suicide process of thymocytes through DNA fragmentation by calcium ionophores and phorbol esters. J. Immunol. 143: 1790-1794

47. Gubina E, Rinaudo MS, Szallasi Z, Blumberg PM and Mufson RA (1998) Overexpression of protein kinase $C$ isoform $\varepsilon$ but not $\delta$ in human interleukin-3dependent cells suppresses apoptosis and induces bcl-2 expression. Blood 91 : $823-829$

48. Mayne GC and Murray AW (1998) Evidence that protein kinase C epsilon mediates phorbol ester inhibition of caslphostin c- and tumor necrosis factoralpha-incuded apoptosis in U937 histiocytic lymphoma cells. J. Biol. Chem. 273: 24115-24121

49. Shao RG, Cao CX and PommierY (1997) Activation of PKC $\alpha$ downstream from caspases during apoptosis induced by 7-hydroxystaurosporine or the topoisomerase inhibitors, camptothecin and etoposide, in human myeloid leukemia HL60 cells. J. Biol. Chem. 272: 31321-31325

50. Seimiya H, Sawabe T, Toho M and Tsuruo T (1995) Phorbol ester-resistant monoblastoid leukemia cells with a functional mitogen-activated protein kinase cascade but without responsive protein tyrosine phosphatases. Oncogene 11 2047-2054

51. KikuchiH, Lizuka R, Sugiyama S, Gon G, MoriH, Arai M, Mizumoto Kand ImajohOhmi S (1996) Monocyte differentiation modulates apoptotic response to cytotoxic anti-Fas antibody and tumor necrosis factor alpha in human monoblast U937 cells. J. Leukoc. Biol. 60: 778-783

52. Boudreau N, Sympson CJ, Werb ZandBissell MJ (1995) Suppression of ICE and apoptosis in mammary epithelial cells by extracellularmatrix. Science 267:891 893

53. MacFarlane M, Cain K, Sun XM, Alnemri ES and Cohen GM (1997) Processing/ activation of at least four interleukin-1 beta converting enzyme-like proteases occurs during the execution phase of apoptosis in human monocytic tumor cells. J. Cell. Biol. 137: 469-479

54. LiH, Bergeron L, Cryns V, Pasternack MS, Zhu H, Shi L, Greenberg A and Yuan J (1997b) Activation of caspase-2 in apoptosis. J. Biol. Chem. 272: 21010-21017

55. Xiang J, Chao DT and Korsmeyer SJ (1996) Bax-induced cell death may not require interleukin 1 beta-converting enzyme-like proteases. Proc. Natl. Acad. Sci. USA 93: $14559-14563$

56. Leverrier $\mathrm{Y}$, Thomas J, Perkins GR, Mangeney M, Collins MKL and Marvel J (1997) In bone marrow derived Baf-3 cells, inhibition of apoptosis by IL-3 is mediated by two independent pathways. Oncogene 14: 425-430

57. Friesen C, Herr I, Krammer PH and Debatin KM (1996) Involvement of the CD95 (APO-1/Fas) receptor/ligand system in drug-induced apoptosis in leukemia cells. Nature Med 2: 574-577

58. Eischen CM, Kottke TJ, Martins LM, Basi GS, Tung JS, Earnshaw WC, Leibson PJ and Kaufmann SH (1997) Comparison of apoptosis in wild-type and Fasresistant cells: chemotherapy-induced apoptosis is not dependent on Fas/fas Ligand interactions. Blood 90: 935-943

59. Herr I, Wilhem D, Bohler T, Angel P and Debatin KM (1997) Activation of CD95 (APO-1/Fas) signaling by ceramide mediated cancer therapy-induced apoptosis. EMBO J. 20: 6200-6208

60. Schlegel J, Peters I, Orrenius S, Miller DK, Thornberry NA, Yamin T and Nicholson DW (1996)CPP32/Apopain is a key interleukin $1 \beta$ converting enzymelike protease involved in Fas-mediated apoptosis. J. Biol. Chem. 271: 1841 1844

61. Bertrand R, Kohn KW, Solary E and Pommier Y (1995) Detection of apoptosisassociated DNA fragmentation using a rapid and quantitative filter binding assay. Drug Develop. Res. 34: 138-144

62. Miller SA, Dykes DD and Polesky HF (1988) A simple salting out procedure for extracting DNA from human nucleated cells. Nucl. Acids Res. 16: 1215 